\title{
406 モ一タ代数によるカム機構動力学解析シミュレーション
}

\section{Dynamic Simulation of Cam Mechanisms using Motor Algebra}

\author{
正 城 道介（茨大） \\ 八幡 光明 (茨大院)
}

Michisuke Jo, Ibaraki University,4-12-1,Nakanarusawa,Hitachi,Ibaraki

Mitsuaki Yahata, Ibaraki University

We have been developing a dynamic simulation system for variety of cam mechanisms. A cam mechanism is composed of three parts connected with three pair axes. Pair axis, velocity, acceleration, momentum and force are represented as a motor. Velocity function and acceleration function derived form cam-diagram are prepared as input data to determine the cam-follower pair axis. Mushroom cam, swinging cam and translation cam are modeled to simulate the motion of cam, follower and supporting link.

Key Words: Motor algebra, Cam mechanism, Dynamic simulation, Link-pair graph

\section{1.はじめに}

現在, 動力学解析の主要のソフトとて ADAMS - DADS 等 などがあげられる.これらは, 機構を $\mathrm{N}$ 体問題として扱って おり, 基本変数と拘束条件が多い. 本研究では, モー夕代数 [1]を用いたカム機構の動力学解析のアルゴリズムを提案す る.モ一夕代数を用いることにより，閉ループ機構においてて, 最小限の変数により運動方程式が記述される.

\section{2. 力ム機構}

カム機構とは, 特殊な形状を持ったカム(原動節)とフォロ ア(従動節)からなる機械的機構のことである. カムを機構学 的に見ると, 運動を変換する機構であり, カムの形状を適切 にすることで，希望するとおりの運動を得ることができる．

カ厶機構の利点として,

・高速で安定しており，信頼性が高い

・再現精度が高い

・同期制御が簡単

などがある。

Fig. 1 に代表的な力ム機構を示す.

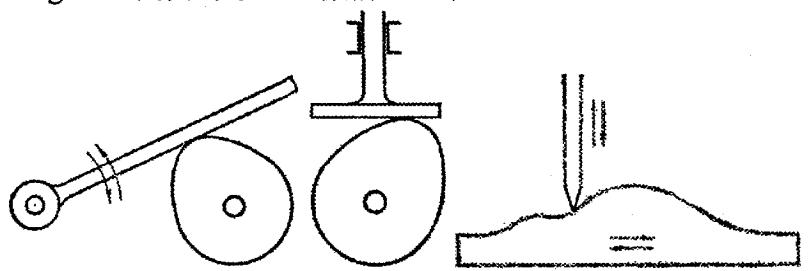

(a)swinging cam (b)mushroom cam (c)translation cam Fig. 1 : Cam Mechanism

カムの回転角に対するフォロアの変位は, カ厶変位関数と して表される. 本研究では, 速度関数, 加速度関数を用いて 機構のシミュレーションを行っている.力ムの回転角を $\theta_{1}$, フォロアの基準点からの変位率を $\theta_{2}$ とすると, 力ム変位関 数は (1)のように表される.これを微分して速度関数(2)， 加速度関数 $(3)$ を求める。

$$
\begin{aligned}
& \theta_{2}=f\left(\theta_{1}\right) \\
& \omega_{2}=\omega_{1} f^{\prime}(\theta) \\
& \alpha_{2}=\alpha_{1} f^{\prime}\left(\theta_{1}\right)+\omega^{2} f^{\prime \prime}\left(\theta_{1}\right)
\end{aligned}
$$

\section{3. 動力学解析システム MODEST}

本システムは Fortran で開発されている。

MODEST の特長の一つは, 入力データから速度関数, 加速度 関数の式を文字列データとして読み込み，数式インタプリタ ルーチンにより計算していることである.

MODEST におけるカム機構の運動方程式 ${ }^{[2]}$ は, 各ペア軸にお けるカ(トルク)の釣り合い式を連立させたものである (4). 基本未知数は，ペア軸における相対角加速度である.

$$
\left[\begin{array}{lr}
{\left[\eta_{j n}\right]} & {\left[S^{*}\right]^{T}} \\
{\left[S^{*}\right]} & {[0]}
\end{array}\right]\left\{\begin{array}{l}
\left\{\alpha_{j}\right\} \\
\left\{X^{*}\right\}
\end{array}\right\}=\left\{\begin{array}{l}
\left\{\tau_{j}+\sigma_{j}\right\} \\
\left\{-Z^{*}\right\}
\end{array}\right\}
$$

$\left[\eta_{\mathrm{ij}}\right]$ は 3 次正方対称行列となる機構慣性行列， $\tau_{\mathrm{j}}$ は外力 と速度により発生するトルク， $\sigma_{j}$ は駆動トルクである. $\left\{Z^{*}\right\}$ は縮小閉路加速度モータ, $\left[\mathrm{S}^{*}\right]$ は, ペアループ基底行列であ る.

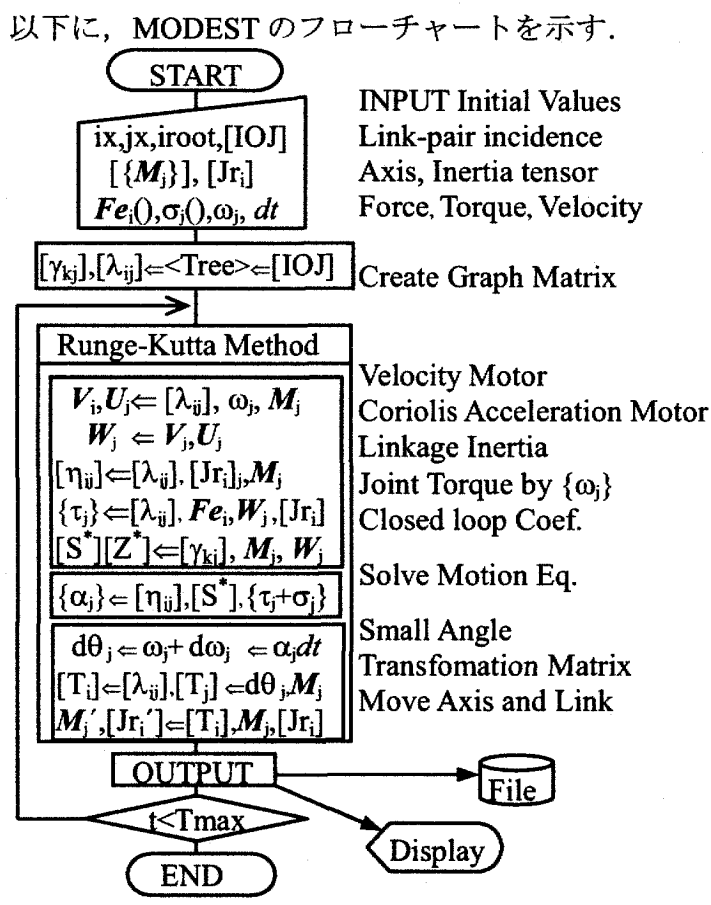

Fig. 2 : Flowchart of System 


\section{4. ペアループ方程式}

4. 1 モータ代数

モータとは, 実数部 $\mathrm{m}$, 微数部 $\mathrm{m}_{0}$ と呼ぶ二つの三次元べ クトルを微数単位 $\varepsilon\left(\varepsilon^{2}=\varepsilon^{3}=\cdots=0\right) に よ り$, 式(5)の形式に 合併したベクトルの拡張形式である.

$$
M=m+\varepsilon m_{o}
$$

モータを用いて, ペア軸, 速度(角速度), 加速度(角加速度), カ(トルク), 運動量(角運動量)を一意に記述できる.

二つのモータ $\mathrm{M}, \mathrm{N}$ から一つのモー夕を求めるモータ積は, 次式で定義される

$$
M \times N=(m \times n)+\varepsilon\left(m \times n_{o}+m_{o} \times n\right)
$$

\section{2 ペア軸モータ}

1 自由度の低次のペアは一つのモータにより記述され，こ れをペア軸モータと呼ぶ。これは，並進ペア，回転ペア，螺 旋ペアの三つに分類される．たとえば，点 $\mathrm{p}=(2,3,4)$ を通る $\mathrm{z}$ 軸回りの回転ぺア軸は，次のように表される.

$$
M=m+\varepsilon(p \times m)=(0,0,1)+\varepsilon(3,-2,0)
$$

\section{3 ペアループ方程式}

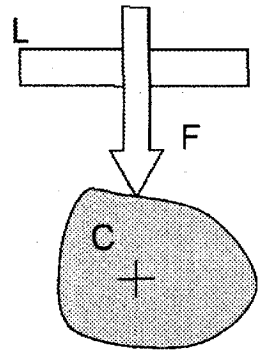

(a)Cam Mechanism

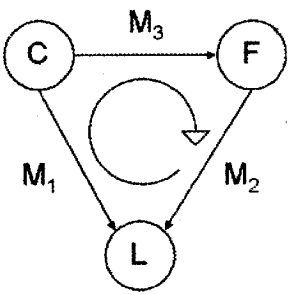

(b)Link-Pair Graph
Fig. 3 : Model of Cam Mechanism

Fig. 3 に示した V 端カムを例にカム機構のモデルについて 述べる. ペア軸 $\mathrm{M}_{1}, \mathrm{M}_{2}$ で支持リンク $\mathrm{L}$ 上に支持されたカム $\mathrm{C}$ とフォロア $\mathrm{F}$ の接触点に仮想のカムペア $\mathrm{M}_{3}$ を考える.こ

こで，Cと FのLに対する相対角速度を $\omega_{1} ， \omega_{2}$ とし，さら に, C の F に対する相対角速度を $\omega_{3}$ とすると, 部品接続グ ラフ(b)より速度に関するペアループ方程式は式(7)の同次 方程式で表される。

$$
-\omega_{1} M_{1}+\omega_{2} M_{2}+\omega_{3} M_{3}=0
$$

カムフォロアペア軸 $\mathrm{M}_{3}$ は，微動するたびに式(8)により 再位置決め ${ }^{[3]}$ する。

$$
U_{3}=\omega_{3} M_{3}=\omega_{1}\left(M_{1}-f^{\prime}\left(\theta_{1}\right) M_{2}\right)
$$

加速度に関するペアループ方程式は式(9)の様な非同次方 程式で表される.

$$
-\alpha_{1} M_{1}+\alpha_{2} M_{2}+\alpha_{3} M_{3}=-Z
$$

Z は閉路加速度モータといい, フォロアに対するカムの相 対速度モータを $\mathrm{U}_{3}$ ，カムフォロアペア軸 $\mathrm{M}_{3}$ の移動速度モー タを $\mathrm{V}_{3}$ とすると，以下の式で表される。

$$
Z=V_{3} \times U_{3}=V_{3} \times \omega_{3} M_{3}
$$

この $\mathrm{V}_{3}$ は, カ厶の種類によって決定される.

\section{5. カム機構のモデル化}

摇り腕力ムを Fig. 4 のように軸間距離 $\mathrm{c}$ (一定)で, 半径 $\mathrm{h}_{1}$, $\mathrm{h}_{2}$ が刻一刻変化する歯車機構としてモデル化する. カムフォ ロアペア軸は， $x$ 軸方向に直進運動し，その移動速度モータ $\mathrm{V}_{3}$ は，式(11)となる。

$$
V_{3}=\left[\begin{array}{llllll}
0 & 0 & 0 & -\frac{f^{\prime \prime}\left(\theta_{1}\right) c \omega_{1}}{\left(f^{\prime}\left(\theta_{1}\right)-1\right)^{2}} & 0 & 0
\end{array}\right]^{T}
$$

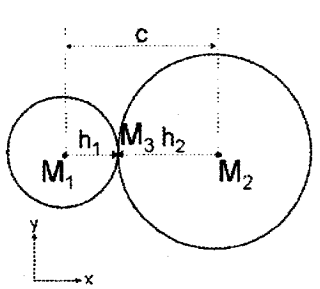

(a)Model

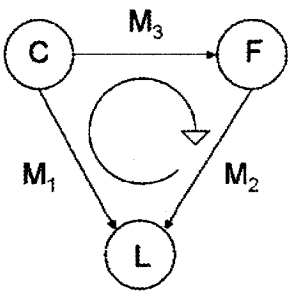

(b) Link-Pair Graph
Fig. 4 : Model of swinging cam

フォロアが直進するV 端カム, きのこ型カムはピニオンの 半径が変化するラックピニオン機構としてモデル化する. カ ムフォロアペア軸は, $\mathrm{x}$ 軸方向に直進運動し，その移動速度 モータ $\mathrm{V}_{3}$ は, 式(12)となる.

$$
V_{3}=\left[\begin{array}{llllll}
0 & 0 & 0 & \omega_{1} f^{n}\left(\theta_{1}\right) & 0 & 0
\end{array}\right]^{T}
$$

カムが左右に動くとフォロアが上下する直動力ムは, 刻一 刻傾きが変化する直進ぺアによりモデル化する. カムフォロ アペア軸は，刻一刻傾きが変化(回転)している，移動速度モ ータ $\mathrm{V}_{3}$ は, 式(13)となる.

$$
V_{3}=\left[\begin{array}{llllll}
0 & 0 & \frac{\omega_{1} f^{\prime \prime}\left(\theta_{1}\right)}{1+f^{\prime}\left(\theta_{1}\right)^{2}} & 0 & 0 & 0
\end{array}\right]^{T}
$$

\section{6. 実行例}

以下に，直動力ムのシミュレーション結果を示す.

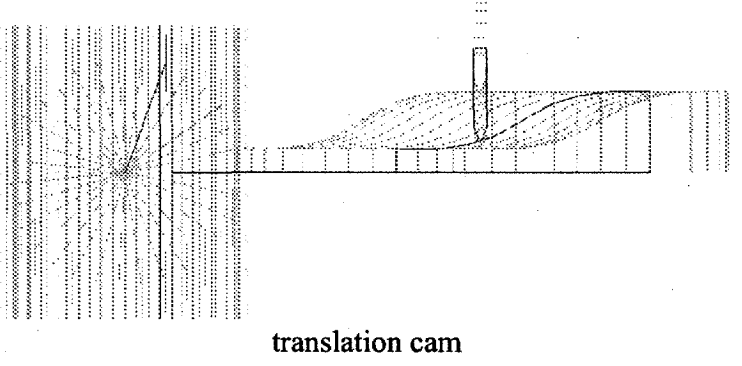

Fig. 5 : Simulation Result

\section{7: おわりに}

各種力么機構の閉路加速度モー夕を定義し, 動力学解析の アルゴリズムを構築した。

今後の課題として

(1)カムとフォロアの衝突接触モデルを作り, 跳躍現象のシ

$$
\text { ミュレーションを行う }
$$

(2)立体カムのモデルを作成する

\section{8. 参考文献}

[1]城道介, 鳥原冬輝 : モータ代数とグラフ理論による機構の記述と 解析(第 1 報) 一自由度の定義と速度解析一，精密工学会誌，54， $7(1988) 1272$

[2]城道介，佐々木智義 : モータ代数とグラフ理論による機構の記述 と解析(第 4 報) 一機構の動力学解析一,精密工学会誌, 61, 4(1995)537 [3]城道介, 松崎知道, 田谷篤嗣, 佐々木智義 : モータ代数とグラフ 理論による機構の記述と解析（第 6 報）一歯車とカムを含む機構の 動力学解析一, 精密工学会誌, 64, 5(1998)715

[4]Michisuke Jo and Tomoyoshi Sasaki : Dynamic Analysis of Mechanisms using Motor Algebra and Graph Theory, Journal of Robotics and Mechatronics Vol.10, No.6, pp.464-474 (1998) 